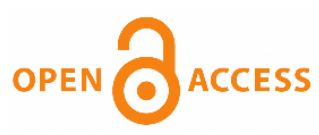

Authors' contribution:

A) conception and design of the study

B) acquisition of data

C) analysis and interpretation of data

D) manuscript preparation

\title{
Practical Role of Philosophy in Sport: Case of Philosophical Consultation
}

\author{
Lukáš Mareš \\ University of South Bohemia, Czech Republic
}

ABSTRACT

The process of philosophical questioning has the power to form not only our way of thinking, but also the way we live. Both my sporting and academic career have made me think about the importance of asking good questions and undergoing the process of answering them. I decided to create a profession of philosophical consultation in sport which works with athletes and coaches of various ages. Consultants and athletes (clients) engage in a dialogue about important and interesting questions/topics in client's life. This dialogical process is called philosophical consultation. It focuses on critical evaluation and development of client's thinking, self-cognition, and attitudes/worldviews. Philosophical consultation helps athletes and coaches to look for their identity and achieve better self-awareness. It can be argued that consultation offers what Patočka calls the "care of the soul" (epimeleia peri tês psychês) or what Foucault calls the "care of the self" (epimeleia heautou), which are based on Socrates' kind of philosophizing. It helps to achieve ancient ideals of kalokagathia and gnôthi seauton. The potential of using philosophy in sport hasn't been fully discovered. Philosophical consultation is presented as a process of self-cognition and inner development. It has the potential to influence the care for well-being of athletes and coaches.

I aim to explore the practical role of philosophy in sport. I will present possible connections between philosophy and sport and the historical predecessors of the concept of philosophical consultancy in sport. As well, we will discuss what philosophical consultancy is, how philosophical consultant works, and finally what are the challenges in bringing philosophical consultation into sport. Methods that are used in this interdisciplinary article are critical textual analysis, description, and interpretation of data.

KEYWORDS philosophy of sport, philosophical consultation, philosophical practice, dialogue, questioning

\section{Types of relationship between philosophy and sport}

There are several types of relationships between philosophy and sport. This text demonstrates the types of relationships that I have been able to identify so far. For example, if we go back to ancient Greece, sport was a popular activity not just among ordinary citizens, but also among the philosophers. According to R.A. Mechikoff (2014, pp. 51-52), H.L. Reid (2007, p. 173), or I. Jirásek (2005, p. 274), philosophers attended the Panhellenic games, some of them even as active participants. Thinkers like Socrates, Plato, and Aristotle 
considered physical activities to be an important part of human life. They made them a part of their philosophy of education. These philosophers thought that through moderate sporting practices, athletes acquire certain virtues and in combination with other types of education, they become good citizens of the polis. There are two types of relationship between philosophy and sport here. One is an active or passive interest in sport among the philosophers - this is not typical just for ancient Greece, but also for later authors like Sartre, Derrida, Camus or Heidegger. The other is the notion that sport has a certain formative dimension and helps human beings to develop as good citizens. In this sense, sport is an important part of the philosophy of education.

Another type of relationship between philosophy and sport is the application of philosophical theories (for example from ethics or philosophical anthropology) on sport (example: Reid, 2012). We may, for instance, say that according to this philosopher or theory, it is not good to allow doping in sports. Or, we may say that in the materialistic paradigm, sport is not an activity with transcendent dimension. Another type of relationship between philosophy and sport is a philosophical analysis of sport (Connor, 2011, pp. 13-15). It is not just the use of philosophical theories of particular philosophers, but a personal reflection of what sport is ${ }^{1}$. The purpose of this inquiry is to identify crucial elements of sport and deepen the understanding of the role of sport in human life.

Philosophy and sport also interconnect when we use our own sporting experience as a starting point for our philosophical thinking and reflection. Hemphill and Smelter (Hemphill \& Smelter, 2008), who use this method, try to introduce philosophy to undergraduate students. Their goal is not to produce philosophers per se, but to promote reflective practitioners who will enter professional fields such as exercise therapy and rehabilitation, teaching and coaching, as well as exercise and sport psychology counselling. Students are asked to write a descriptive and reflective account of a significant personal experience in a sport or leisure related activity, then they are exposed to narratives of the lived experiences of others.

Last but not least, the type of relation between philosophy and sport is the use of philosophical consultancy in sport. Trained philosophers or consultants use a method of dialogue and philosophical questioning in order to work with athletes and coaches. Tools that are used during the session are the identification of the question or topic that the athlete or coach considers important for their life. Then the philosopher uses tactics of conceptualisation, argumentation, clarification, distinction, deepening questions, problematization, creation of hypotheses, mind experiments, reflection, goal/vision/intention/dream settings and their critical evaluation, for a thorough analysis of the sport situations. This process aims at finding personal identity, producing selfawareness, clarifying of thinking, and a better understanding of athlete's and coach's place in the sporting and non-sporting world. On a general level, it aims at taking care of athlete's and coach's soul/self ${ }^{2}$.

\section{Historical predecessors of the concept of philosophical consultancy in sport}

Philosophy and sport were closely intertwined in ancient Greece. Evidence for this statement can be found in the Greek system of education and personal development. Young men, competitive and excited to work on their body and soul in order to achieve aretê $\hat{e}^{3}$ liked to spend their time in places called gymnasia. According to H. L. Reid (2012, p. 12),

\footnotetext{
${ }^{1}$ According to J. Kosiewicz, philosophy of sport has only initiated some process of structuralisation. Until the process of forming of a new discipline is finished, we will face philosophical reflections on sport rather than the philosophy of sport (Kosiewicz, 2006, p. 53).

${ }^{2}$ Presented types of relationship between philosophy and sport naturally tend to blend, but it does not exclude that they can be distinguished as different types of relationship.

${ }^{3}$ This complicated term could be translated as perfection or virtue, it is however difficult to capture by words what arete is, because it is not clare et distincte (for more info see Hogenová, A. (2001). Areté: základ olympijské filosofie [Aretê: foundation of Olympic philosophy].).
} 
"Ancient gymnasia were more like modern parks: open-air spaces with easy access to water and room for running, wrestling, and other sports. Sometimes they included covered colonnades to protect athletes from the sun and rain. There might also have been facilities for undressing and oiling the skin, as well as storage rooms and bathing facilities".

Gymnasia were not just sporting facilities, but rather they were centres of various social events (Olivová, 1985, p. 131).

Ancient gymnasia were also popular among philosophers. H. L. Reid (2011, p. 44; 2012, pp. 10, 145-146) speaks about Pythagoras ( $6^{\text {th }}$ century BC.) who is said to have recruited a young athlete to philosophy, first by paying him to study and then by eventually enticing to pay him for his lessons. Probably the most well-known figure in the 5th century Athens is Socrates, who was also interested in winning the youth over to philosophy, but unlike Pythagoras, Socrates was not after money. He was oriented at arête, which for him was a type of wisdom that enabled people to live a virtuous life. He saw physical activities as an important part of human life; nevertheless they were not the ultimate end for him. Olivová $(1985$, p. 136) mentions that Socrates was a gymnast and dancer; however, he was primarily interested in philosophical discussions. His method of dialogue is based on asking questions. It can be argued that the whole process has one ultimate goal - to awake the partner in the dialogue by showing him the discrepancies in his thinking. According to Šulavíková (2011, p. 158), Socrates was a "practical philosopher": "he is known to have related his thinking to his own actions, forcing others to do so as well".

My interpretation of Socrates is that he wanted to awaken people from their unexamined life and push them towards philosophical life. This life consisted in being aware of who one is and in acting in accordance with virtue. His "clients" were citizens of Athens, and included athletes. Most of them did not like Socrates, because by asking questions, he set a mirror for them and made them see who they really were. When talking to Socrates, people's masks of opinions about their "truth", that being either about oneself or about certain topic, were taken off. This awakening consisted in searching for epistêmê (knowledge) instead of doxa (opinion) was unbearable for them, so Athenians decided to get rid of Socrates. However, despite their effort, they could not get rid of the legacy that this philosopher left behind. It is the simple idea that only the examined life in accordance with virtue and truth is worth living. Socrates viewpoint was that philosophy, being considered as the process of selfexamination, self-development, and examination of important topics in our life, is an important part in human life, and so also it is in an athlete's life.

What philosophers like Socrates, Plato, and others represented in their age is the ideal of kalokagathia ${ }^{4}$, which on one level can be understood as a balance between soul (psychê) and body (sôma) development. This balance presupposes that physical education without taking care of the soul is not satisfactory for human flourishing just as it is not satisfactory to take care of the soul without taking care of the body. Jirásek (2005, p. 218) states that the ideal of kalokagathia was realized through practical education (paideia), which puts emphasis on the bodies development by doing physical exercises as well as on the development of human consciousness through philosophical discussions. Paideia consisted of gymnastic education (gymnastikê) $)^{5}$ and of the art of the Muses (mousikê), which both together enabled young individuals to flourish complexly. Kalokagathia is an important concept behind the idea of philosophical consultancy in sport. The point is to find a balance between the sporting career (moderate physical exercises) and taking care of the soul. Ancient philosophers like Socrates and Plato saw these two phenomena as interconnected and as conditions for living a good life.

\footnotetext{
${ }^{4}$ From Greek kalos (beautiful), kai (and), agathos (good, noble). For a complex discussion about kalokagathia see Martínková, I. (2012). Jak rozumét kalokagathii? [How to understand kalokagathia?].

5 According to Jirásek, Oborný and Hurych, ,the ancient gymnastics could be perceived as a harmony of sport and movement culture (it means sport without any attribute), and as the authentic mode of sport influenced by a natural human power and its harmonical development " (Jirásek, Oborný, \& Hurych 2018, p. 5).
} 
Living a good live life was a central topic for most ancient Greek philosophers. French author Pierre Hadot speaks about ancient philosophy as way of life. This approach is in opposition to the theoretical conception of philosophy as a way how to create mind constructs about reality. Hadot emphasized that ancient Greek philosophers did not just philosophize, but they lived the philosophical life. Having in mind that what matters is a good life, they investigated themselves and the world around them. They also used spiritual exercises in order to live in accordance with what their philosophical school considered to be good. Hadot states about ancient philosophy this (Hadot, 1995, pp. 59):

\section{"Each school ...represents a form of life defined by an ideal of wisdom... every school practices exercises designed to ensure spiritual progress toward the ideal state of wisdom, exercises of reason that will be, for the soul, analogous to the athlete's training or to the application of a medical cure".}

When I speak about philosophical consultancy in general and in sport, I consider philosophy to be a way of life. French philosophical practitioner O. Brenifier (p. 123) states that this practical dimension of philosophy does not really innovate, insofar as it represents a return to original concerns, to the quest of wisdom that articulated the very term of philosophy. He adds that this dimension "has been relatively obscured for several centuries by the 'learned' facet of philosophy". It could be argued that philosophy in the form of philosophical consultancy is similar to its antique version. It aims not only at asking important questions and looking for answers to them, but also at living a good life in accordance with the results of each personal investigation.

\section{What is philosophical consultancy?}

Philosophical counselling and consultancy is part of the larger domain called 'philosophical practice' ${ }^{6}$, which includes philosophical workshops (with groups or organisations), philosophy for children (P4C), philosophical coaching/training, and personal philosophizing. A person that engages in at least one of these areas can be entitled as philosophical practitioner. Despite its strong roots in ancient Greece, philosophical counselling and consultancy does not have a long tradition. According to D. Louw (2013, p. 60), founder of philosophical counselling (PC) is German philosopher Gerd B. Achenbach. In 1980's, he founded Gesellschaft für Philosophische Praxis and started his personal practice. The idea of philosophical conselling and consultancy became popular and it expanded all around the world (Louw, 2013, p. 60; Brenifier, p. 123). There are now organisations and institutes ${ }^{7}$, journals ${ }^{8}$ and books, training programs, and even master's degree program in Romania for those who want to become counsellors and consultants. ${ }^{9}$ The most influential figures regarding philosophical practice are Lou Marinoff, Oscar Brenifier, Ran Lahav, Shlomit Schuster, and Peter Raabe. It is hard to find people in the Czech Republic who focus on philosophical counselling and consultancy. There are

\footnotetext{
${ }^{6}$ A distinction must be made between philosophical practice, academic (general/theoretical) philosophy (for example metaphysics, which is purely theoretical), practical philosophy (for example ethics, which offers theoretical foundations for human action), applied philosophy (often interdisciplinary, it focuses on matters of practical concern - example: applied ethics), and experimental philosophy (part of applied philosophy - it focuses on usage of systematic experiments aimed at understanding how people ordinarily think about the issues at the foundations of philosophical discussions). Philosophical practice, unlike aforementioned disciplines/fields, could be characterized as a philosophy that directly focuses on selfcognition, self-development, cognition of others, and on cognizing the world and life in general. It is the direct focus on self-cognition and self-development that distinguishes philosophical practice from other disciplines/fields of philosophy.

7 Well-known are for example American Philosophical Practitioners Association (APPA, https://appa.edu/), National Philosophical Counseling Association (NPCA, http://npcassoc.org/), and Institute of Philosophical Pracice (https://www.pratiques-philosophiques.com/eng).

${ }^{8}$ Philosophical Practice - journal of the APPA.

9 West University of Timisoara, Program: Philosophical Counselling and Consultancy, link: https://www.mastersportal.com/studies/149240/philosophical-counselling-and-consultancy.html. Retrieved March 14 2019.
} 
a few student theses ${ }^{10}$ and one critical publication ${ }^{11}$ reflecting selective features of philosophical counselling and consultancy, but as far as I know, very little use of philosophy in practice.

A distinction can be made between counsellors and consultants, based on their competencies. Probably the main difference is that philosophical consultants do not address mental disorders, whereas philosophical counsellors due to their special training can. ${ }^{12}$ Philosophical consultants set mirrors for their clients by asking them questions and by demonstrating their clients their thinking processes, whereas counsellors rather advise people on their personal life philosophy (Šulavíková, 2011, p. 157). There has been an extensive debate about the differences and similarities between PC and psychotherapy and also between PC and academic philosophy. I will not address this issue here, but I offer tips for further reading. ${ }^{13}$ Philosophical consultants, which I focus on in this article, differ in their methods, styles, and areas of interest. O. Brenifier (p. 123) states that "methods vary enormously depending on the practitioners who design and apply them". Some methods and styles of consultation are quite similar to coaching and psychotherapy and it will remain a big challenge to distinguish between these areas.

Brenifier mentions two specific and common prejudices that can be said about the philosophical consultation. The first prejudice consists in believing that the practice of philosophy (and thus of philosophical discussion) is reserved only for a learned elite, and so philosophical consultation is not for everybody. The second prejudice says that philosophical consultation cannot be philosophical since it is open to all. It is based on thinking that philosophy is reserved only for scholarly elite. Brenifier tries to refute these prejudices. His strategy is based on so called 'philosophical naturalism'. This concept "presupposes that the emergence of philosophy is not a particular event, but that its living substance nests in the heart of man and lines his soul..." (Brenifier, p. 124). For Brenifier, philosophical inquiry is natural for man. It is therefore possible to state that everyone may philosophize (though under certain conditions) and that this inquiry is really philosophical ${ }^{14}$.

There is no universal definition of what philosophical consultancy or counselling is. D. Louw (2013, p. 67) offers this minimal definition: "PC involves a trained philosopher helping an individual to deal with his/her problem". This definition (or rather characteristic) explicitly mentions that the consultant is a trained philosopher. This requirement is recognized also by NPCA: “... philosophical consultants hold a minimum of a Masters degree in philosophy from a recognized graduate program "15. D. Louw (2013, p. 67) also offers a complex definition that may capture the most prominent traits of PC:

\footnotetext{
${ }^{10}$ For example ,Co je specifické pro filosofické poradenství? [ What is specific for philosophical counselling?] (Kopt'ová, 2014), ,Filosofická praxe a poradenstvi" [Philosophical practice and counselling] (Helmich, 2013), ,Filosofické poradenstvi' [Philosophical counselling] (Koptová, 2012).

${ }^{11}$ Horák. O. (2015). Filozofické poradenstvo/kritika [Philosophical counselling/critique]. Olomouc: Palacký University.

${ }^{12}$ For more info see: http://npcassoc.org/practice-areas-boundaries/.

${ }^{13}$ For example M. Rovira - Psychology is the child of philosophy: an interview with Lou Marinoff (2017), L. Marinoff Playing with ideas: an interview with Lou Marinoff (2016), D. Louw - Defining philosophical counselling: an overview (2013), B. Šulavíková - Questions for philosophical counselling (2012), J. Śulavík - Problém vzt’ahu filozofie a psychoterapie [Problem of the relationship between philosophy and psychotherapy] (2001), A. Howard - What can philosophy offer counselling and psychotherapy? (2000), M. Gole - Clinical philosophy in the treatment of paranoid schizophrenia and obsessive-compulsive disorder (2015).

14 This concept needs clarification. What is meant by 'philosophical' here is a process of inquiry rather than a particular philosophical system. However, if we want to find philosophical system behind the idea of philosophical consultancy, it would be pragmatism with its focus on a practical impact of thinking on our life. Philosophical consultation as a method of inquiry also has a phenomenological background and with its focus on language and verbal expressions has a connection to analytic philosophy (philosophy of language).

${ }^{15} \mathrm{http} / / /$ npcassoc.org/practice-areas-boundaries/. Retrieved March 14 2019. It should be noted that this requirement applies to countries and organisations with developed concept of philosophical practice. So far, Czech Republic does not have any concrete requirements for philosophical consultants and counsellors. There are neither courses nor trainings for candidates yet.
} 
"PC embodies the process wherein I, a trained philosopher, professionally care for you, my client or guest. I care for your self and world (and thereby for my self and world) by applying my training in philosophical skills and theory to address your problem... I can address your problem only in so far as it involves sane, yet confused or obstructed thinking (i.e. reasoning or conceiving), and not in so far as it involves physiological or neuropsychiatric dysfunction. I do so (self-)critically and creatively in a dialogical partnership with you... Through our probing and prompting questions we continually co-create a space within which both of us may find and keep finding our own ways of dealing with the problem in question...".

A question can be raised about the impact of philosophical consultation and counselling on client's life. It seems that impact depends and can be measured based on the explicit goal of philosophical consultation and counselling. ${ }^{16}$ J. Sulavík (2001, p. 591) states that the goal of philosophical counselling is practical wisdom. B. Šulavíková (2011, p. 157) believes that it is the "good life"17 that is central to the agenda of philosophical practice. She sees PC as "a conversational process that controls dialectic thinking and reflects the fears and questions that arise in everyday life as well as questions about meaning of life as a whole”. Philosophical dialogue is according to this author a space for seeking a good life, identity and critical thinking. Marinoff (2016, p. 5) sees philosophical inquiry as a playful activity: "philosophy is to some extent a play of, and with, ideas". Even though philosophy is often connected with deep thinking and seriousness, there is a place for play ${ }^{18}$, humor, and fun in it. Marinoff $(2016$, p. 8) states that "humor may catalyze the learning of philosophical argument". It also helps to take a distance from ourselves and the topic that we are dealing with, which is an important condition for philosophizing.

Philosophical consultants may deal with several types of problems and topics. NPCA offers a list of examples among which we may find moral issues, values disagreements, time management issues, retirement, problems with family, falling in and out of love, friendship issues, rejection or discrimination. ${ }^{19}$ Topics and problems vary depending on the interests of a particular client.

\section{Philosophical consultancy in sport}

So far, I have not found anyone who would be interested in philosophical consultancy in sport. Nevertheless, there are attempts that focus on using philosophy in sport. What exists is professional philosophy as one of the fundamental elements of effective sport psychology consulting practice. ${ }^{20}$ It can be argued that philosophical consultation is the same, or at least similar, to an existential approach to sport psychology. Ronkainen and Nesti (2015) maintain that this approach

"contributes to sport psychology by bringing neglected concepts including courage, authenticity, spirituality and personal meaning into the centre of research and applied practice...existential sport psychology is more concerned about understanding the subjective reality of sport participants and meanings they assign to their experiences than developing universal theories to predict and enhance athletic performance".

\footnotetext{
${ }^{16}$ Although empirical research can provide relevant data about the impact and efficiency of philosophical consultation and counselling, it can be argued that we can see the positivity of philosophical consultation without empirical data, but just rationally based on the philosophical analysis of human being and his relation to the world. Nevertheless, it is important to analyse what are the attributes of good philosophical consultation and counselling.

${ }^{17}$ Using definite article here could mean that this good life is rather objective than subjective.

${ }^{18}$ Some authors argue that ludity (playfulness) forms the substance of sport (Jirásek, Oborný, \& Hurych 2018, p. 8). Therefore, philosophy and sport may be linked by play.

${ }^{19} \mathrm{http} / / / \mathrm{npcassoc}$.org/practice-areas-boundaries/. Retrieved March 142019.

${ }^{20}$ For more info see for example article Professional Philosophy: Inside the Delivery of Sport Psychology Service at Team Denmark (2011) written by K. Henriksen.
} 
I maintain here that philosophical consultancy in sport has its specific set of methods and goals that makes it an autonomous area. Nevertheless, similarities with psychotherapeutic approaches, sport psychology methods, and coaching styles ${ }^{21}$ are indisputable.

Another discipline/field that shares some topics and methods with philosophical consultation is sport chaplaincy. The aim of sport chaplains is to provide spiritual and pastoral care to professional and amateur sport. According to Sport Chaplaincy UK, sport chaplain is expected to provide "ongoing pastoral and spiritual care, by permission, to those of faith or no faith, for the holistic well-being of all involved in the community of sport." 22 Philosophical consultant also cares for his or her client, but in a different way than sport chaplains. Although both professions use the method of dialogue, they differ in their style and purpose. Philosophical consultant does not provide pastoral and spiritual care, but rather a philosophical care. Religion, faith, and spirituality ${ }^{23}$ may be part of the philosophical discussion, but consultant is not proactive regarding how things are. Rather he uses the strategy of philosophical dialogue to set a mirror for client's thinking. The starting point for consultants is rationality, whereas the starting point for chaplains is faith and/or spirituality. ${ }^{24}$

Philosophical consultants and clients may focus on topics such as dealing with fear, understanding one's role in the team, school and sport balance, finding purpose, sport's identity reflection, goal/vision/purpose/dream evaluation or understanding of my sport. The main purpose of philosophical consultation with an athlete or coach is to challenge and clarify his or her thinking, promote his or her self-awareness, and deepen his or her understanding of self and the world. The purpose is not to heal, but on general level to take care of the client's soul $^{25}$. Consultants focuses on the worldviews and attitudes of their clients, critically examines them and if needed, substitute them by better ones. ${ }^{26}$ This all happens in a dialogue between consultant and client. The key part of this process is philosophical questioning.

I'm interested in philosophical consultancy in sport because of my hockey career and academic background in philosophy. I work mainly with young hockey players and their thinking in order to achieve clarity in it. As well, I work with the attitudes and worldviews that shape their everyday actions. What I use during my work is philosophical dialogue. The main purpose of philosophical dialogue is not to enhance the player's performance. It aims not at creating better athletes, but rather on awakening them. ${ }^{27}$ Its central part is questioning that presupposes certain lack of knowledge on both sides. Consultant and client wish to know something, one about the other and the topic, the other about himself or certain topic in his life. Brenifier (Brenifier, p. 10) distinguishes between philosophers and sophists based on their relation to knowledge: "According to the tradition, the philosopher differs from the sophist. For, if the former wishes to know, the latter is already in possession of this knowledge". Philosophical sessions presuppose that the client wishes to know and is therefore open to philosophizing.

\footnotetext{
${ }^{21}$ For more info about coaching in sport and other areas in human life see for example book series The Inner Game written by Timothy Gallwey.

${ }^{22}$ Retrieved April 102019 from https://sportschaplaincy.org.uk/what-does-a-chaplain-do/.

${ }^{23}$ For more info about religion and spirituality in sport see for example articles Religion and Spirituality in Sport (2018) and Religion, Spirituality, and Sport: From Religio Athletae Toward Spiritus Athletae (2015) written by Ivo Jirásek.

${ }^{24}$ This does not mean that rationality and faith/spirituality are in opposition. It only suggests that consultant and chaplains differ in their approach toward their clients based on their worldviews and goals.

25 This statement does not presuppose or refer to metaphysical dualism. It only tries to capture the focus of philosophical consultation, which is mainly concerned with mental processes. Nevertheless, these processes have impact on the human being, not only on the mental side. The author of this article consider himself to be closer to holistic rather than dualistic approach toward the human being.

${ }^{26}$ According to Marinoff, "to change one's philosophy is what makes the difference to one's personal evolution toward a fulfilled life" (Rovira, 2017, p. 7). I consider worldviews and attitudes to be main constituents of personal life philosophy. ${ }^{27}$ When I want to enhance player's performance, I focus more on the methods from coaching and sport psychology.
} 
Player or coach is free to choose whether he wants to engage in a philosophical dialogue. In most cases, people that are interested in having a dialogue have a concrete topic that they want to discuss. I will focus here on players rather than on coaches, because I have a bigger experience with them. Cooperation with younger players usually starts from the initiative of their parents. If the player is younger than 18, I meet with his parents regularly, so they can have a general idea what the cooperation is about and what results we have reached. The philosophical consultation is predominantly a one-on-one process.$^{28}$ Usually the cooperation starts with player's question..$^{29}$ It is not any question, but the one that is important for the player. The client is asked to write down the question, which gives boundaries to his thinking, makes his interest visible and therefore open for further analysis. Initial questions are not always philosophical, but there is always a philosophical background behind them. Examples of such questions are:

- Why don't I always play at $100 \%$ ?

- What would be the meaning of my life if I did not play hockey?

- How do I get rid of my fear?

- How can I be calm in the game?

- How to think positively?

When the question is asked, the process of the philosophical dialogue may begin. I don't consider a player to be my patient or a person that needs psychological help, but rather a partner in the thinking process. As a consultant, I ask questions that make my client think. I ask these questions based on client's answers and presuppositions they contain. We don't just talk. Our dialogue is philosophical, because it contains argumentation, problematization, clarification, conceptualisation, deepening, distinction, creation of hypotheses, mind experiments, reflection, search for truth and understanding, and most importantly, it endeavours to know thyself and overcome thyself.

The initial question of the player is not as important as the client himself that is behind the question. ${ }^{30}$ Therefore, what I try to offer to the player is not an answer, but rather another question that opens the thinking process. ${ }^{31}$ The goal is not to find the exact answer. We aim at the process of self-development through the thinking process. When a player does not know, consultant offers an idea that the player may use as a material for his thinking. The dialogue is structured. Consultant takes notes that serve him as a basis for his questioning strategy. Client is also asked to write down his answers/ideas. The purpose of this is to bring clarity to the session by making thoughts visible. Players often realize that working with oneself is a complicated task. The answers that we reach (for example 'in order to get rid of my fear, I need to learn how to be in a game', or 'in order to be calm, I need to learn to be with myself') function not only as practical opportunities for self-development, but also as a material for further analysis. The ideal is that the player or coach leaves the session with a certain level of clarity in his thinking, with deeper understanding of himself and the topic that we focused on, and with new idea what would be good to do next. Cooperation can be short-term (1-5 sessions) or long-term (5-approx. 10 sessions) based on client's preferences and areas of interest. It is for players of various ages. Cooperation usually differs in length (usually between 45-90 minutes), form and content based on the age of the player.

When working with younger hockey players (age 10-15), I focus on playful activities, on stimulating wonder and on learning basic philosophical skills so the player is prepare to philosophize. With older players (age 15-

\footnotetext{
${ }^{28}$ Exceptionally I have a session with two players. The condition for this is that players know each other well and are ok with this type of cooperation. Advantage of this cooperation is that one player may function as a mirror for the other.

${ }^{29}$ When a player does not have a question, we continue in the work from our last session or I offer him possible topics that might be interesting and useful for him.

${ }^{30}$ According to Oscar Brenifier, the word itself, which is a necessary constituent of any question, indicates an author, his preoccupations, his emotions, his way of being, his particular thinking.

${ }^{31}$ Example: Client's question is 'Why don't I always play at $100 \%$ ?'. Consultant then may use reflective question that will direct the attention more on the client: 'Why is the answer to this question important for you?'. Another possible strategy is to ask the client to give at least 3 hypotheses as rational answers to his question and then critically evaluate their validity.
} 
20), the cooperation is more intellectually demanding. ${ }^{32} \mathrm{We}$ engage in a dialogue with specific rules and goal. If the initial question is practical (for example 'How to get rid of my fear?'), we also use specific physical and mental exercises in which we focus on breathing, controlling of thoughts, and dealing with emotions. I put emphasis on reflecting these exercises so the player will do what suits him the most.

\section{Challenges in bringing philosophical consultation into sport}

There are several challenges in bringing philosophical consultation into sport. Here are four of them based on my personal experience:

a) Taking distance from our own ego - it is tempting to have paternal approach during the consultation or to be stuck with oneself; the challenge is to focus on a client and his thinking rather than on being only with oneself.

b) Distinction between what is philosophical and what is not - if a consultant is not able to distinguish between that, consultation and the whole practice may easily become vague. It is therefore important to constantly educate oneself and reflect on one's work.

c) Adaptation to the sport environment - the consultant should be able to combine his philosophical expertise with interests and thinking level of his clients and make his or her speech understandable.

d) Gaining trust - since philosophical consultation is unknown to most athletes and coaches, consultant faces the challenge to gain their trust by working on himself and by doing his work properly.

\section{Conclusion}

Philosophy and sport could interconnect on several levels. One of them is the use of philosophical dialogue with athletes and coaches to work on their inner development. This interconnection between philosophy and sport has its roots in ancient Greece, where philosophy and sporting practice were united in the ideal of kalokagathia. Taking care of the soul as well as of the body is not only a theoretical concept, but primarily a way how to flourish as a human being. The idea of philosophical consultancy connected with sport seems to be a good way how to achieve this flourishing. Nevertheless, it should be noted that human flourishing is a complex idea. Both sport and philosophical practice are important for achieving it, but not sufficient. Living a good life, which I presuppose to be the goal of a human being in general, consist in more than playing sport and philosophizing. On the other hand, it could be argued that these two activities, when done properly, are part of living a good life due to the positive qualities they have.

This article tries to introduce the concept of philosophical consultancy in sport. There are practically no texts that would deal with this topic, so it is clear that further inquiry is needed. Usage of philosophy in modern sport practices contains a potential not only for an academic research (both theoretical and empirical), but most importantly for player's and coach's personal development.

\section{REFERENCES}

Brenifier, O. The art of philosophical practice. Retrieved March 16, 2019, from http://www.pratiquesphilosophiques.fr/en/welcome/?lang=en.

Connor, S. (2011). A philosophy of sport. London, UK: Reaktion Books.

Hadot, P. (1995). Philosophy as a way of life. Oxfor, UK: Blackwell Publishers Ltd.

Hemphill, D., \& Smelter, R. (2008). Philosophy and reflective practice in sport studies. Retrieved March 16, 2019, from http://www.society-for-philosophy-in-practice.org/journal/pdf/9-1\%2023\%20Hemphill\%20-\%20Sports\%20Studies.pdf.

\footnotetext{
${ }^{32}$ Oscar Brenifier considers speech in philosophical practice to be more rigorous, harsher, more demanding than speeches in other contexts.
} 
Jirásek, I. (2005). Filosofická kinantropologie: setkání filosofie, těla a pohybu [Philosophical kinanthropology: meeting of philosophy, body, and movement]. Olomouc, Czech Republic: Palacký University.

Jirásek, I., Oborný, J., Hurych, E. (2018). The authentic and inauthentic sport in the hermeneutic and phenomenological perspectives. Acta Facultatis Educationis Physicae Universitatis Comenianae, 58(1), 1-11. DOI 10.2478/afepuc-20180001 .

Kosiewicz, J. (2006). Philosophy of sport or philosophical reflection on sport. Acta Universitatis Palackianae Olomucensis. Gymnica, 36(2), 53-58.

Louw, D. (2013). Defining Philosophical Counselling: An Overview. South African Journal of Philosophy, 32(1), 60-70.

Marinoff, L. (2016). Playing with ideas: an interview with Lou Marinoff. American Journal of Play, 9(1), 1-17. Retrieved March 16, 2019, from http://www.journalofplay.org/sites/www.journalofplay.org/files/pdf-articles/9-1-interview-playingwith-ideas.pdf.

Mechikoff, R. A. (2014). A history and philosophy of sport and physical education: from ancient civilization to the modern world. New York, USA: McGraw-Hill.

Olivová, V. (1985). Sport a hry ve starověkém světě [Sport and games in ancient world]. Prague, Czech Republic: Artia.

Reid, H.L. (2011). Athletics and philosophy in ancient world: contest of virtue. Abingdon: Routledge (Taylor \& Francis Group).

Reid, H.L. (2007). Sport and moral education in Plato's Republic. Journal of the Philosophy of Sport, 34(2), 160-175. DOI: 10.1080/00948705.2007.9714719.

Reid, H.L. (2012). Introduction to the philosophy of sport. Plymouth, UK: Rowman \& Littlefield Publishers, Inc.

Ronkainen, N. J., \& Nesti, M. S. (2015). An existential approach to sport psychology: Theory and applied practice. International Journal of Sport and Exercise Psychology, 15(1), 12-24. DOI: 10.1080/1612197X.2015.1055288.

Rovira, M. (2017). Psychology is the child of philosophy: an interview with Lou Marinoff. EC Psychology and Psychiatry 4.1 (2017), 6-14. Retrieved March 16, 2019, from https://www.ecronicon.com/ecpp/pdf/ECPP-04-00111.pdf.

Sulavík, J. (2001). Problém vzt’ahu filozofie a psychoterapie [Problem of the relationship between philosophy and psychotherapy]. Filosofický časopis, 49(1), 585-601.

Šulavíková, B. (2011). Philosophical dialogue as a space for seeking a good life, identity and critical thinking. Human Affairs, 21(2), 157-162. DOI: 10.2478/s13374-011-0017-5.

\section{Web pages}

http://npcassoc.org/practice-areas-boundaries/. Retrieved March 142019.

https://sportschaplaincy.org.uk/what-does-a-chaplain-do/. Retrieved April 102019.

\section{AUTHOR'S ADDRESS:}

Lukáš Mareš

University of South Bohemia

Faculty of Theology

Kněžská 8, 37001

České Budějovice

Czech Republic

E-mail: 1.marysta@seznam.cz

Received: 14 March 2019; Accepted: 17 April 2019 